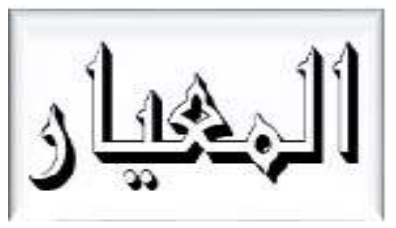

Al Mi'yar

Vol. 3, No. 2, Oktober 2020

P-ISSN: 2620-6749, E-ISSN: 2620-6536

DOI: $10.35931 / a m . v 3 i 1.341$

\title{
TELAAH SEMIOTIK PENDIDIKAN NASIONALISME DALAM PUISI “RISĀLAH MIN AL MU'TAQIL" KARYA SĀMIH AL-QĀSIM
}

\author{
Ghulam Falach', Ridhatullah Assya'bani' \\ Sekolah Tinggi Teknologi Kedirgantaraan (STTKD) Yogyakarta ${ }^{1}$ \\ Sekolah Tinggi Ilmu Alqur'an (STIQ) Amuntai²
}

Email: afha71@gmail.com¹, rassyabani@gmail.com²

\begin{abstract}
The used title of this study cones on the work of poetry Samih al-Qasim where he is one of the revolutionary poets of the modern age in Palestine. As a journalist, Samih alQasim tried to express his fighting spirit through poetry bait to ignite the spirit of Nationalism Education for Palestinian youths. Although many researchers have discussed his poetry, but researchers have not yet discussed the nationalism education contained in the poem Samih al-Qasim. The purpose of this review is not only to show the meaning throughout al-Qasim's poetry, but also for the purpose of the poet's use of the poetic text. This research discusses using qualitative research to analyze the educational values of nationalism in the Samih al-Qasim quote through the knife of semiotic analysis. This method is used to present the interaction between the text with personal and cultural experiences from the reading of signs in the form of words, sentences and paragraphs that contain poetry Samih Al-Qasim. In order to make it more functional, this discussion is accompanied by a descriptive presentation of the discussion so that it is produced which contains the values of the spirit of nationalism in the poem by Samih al Qasim that can be useful and improved.
\end{abstract}

Keywords: Nationalism Education, Adab al Muqawwamah, Semiotics, Samih al-Qasim

\begin{abstract}
Abstrak
Pemilihan judul kajian ini mengerucut pada puisi karya Samih al-Qasim dimana beliau merupakan salah satu penyair revolusioner abad modern di Palestina. Sebagai seorang jurnalis, Samih al-Qasim mencoba menyuarakan semangat juangnya melalui bait puisi untuk mengobarkan api semangat Pendidikan Nasionalisme untuk pemuda-pemudi Palestina. Meskipun banyak peneliti telah membahas puisinya, namun para peneliti belum menyentuh Pendidikan nasionalisme yang terkandung pada puisi Samih alQasim. Tujuan kajian ini tidak hanya untuk menunjukkan makna di seluruh puisi alQasim, tetapi juga untuk menyelidiki tujuan penyair menggunakan teks puisinya. Pembahasan ini sepenuhnya menggunakan penelitian kualitatif untuk menganalisis nilai-nilai pendidikan nasionalisme pada puisi Samih al-Qasim melalui pisau analisa
\end{abstract}


semiotika. Metode ini digunakan untuk menghadirkan interaksi antara teks dengan pengalaman personal dan kultural dari pembacaan tanda berupa kutipan-kutipan kata, kalimat, dan paragraph yang terdapat dalam puisi Samih Al-Qasim. Agar dapat lebih difungsikan, maka dalam penulisan ini dilengkapi penyajian pembahasan secara deskriptif sehingga kajian yang dihasilkan berupa kandungan nilai-nilai semangat nasionalisme dalam puisi karya Samih al Qasim dapat bermanfaat dan komprehensif.

Kata kunci: Pendidikan Nasionalisme, Adab al Muqawwamah, Semiotik, Samih alQasim

\section{PENDAHULUAN}

Pasca pendudukan Israel secara besar-besaran di Palestina pada Mei 1948, lahirlah gelombang generasi pertama Sastrawan Arab-Palestina yang melakukan perlawanan melalui karya sastra. Di antaranya adalah Mahmud alHut, Muhammad al-Adnaniy, Kamal Nașir, Muhammad al-Izzah, Abu Salma, Yusuf al-Khatib, Khalil Zaqțan, Harun Hasyim Rasyid, dan Mu`yyan Basisu, Da`d al-Kayaliy, Samirah Abu Gazalah, Lamya Șayig, Salma Khadra al-Jayyusiy, dan Fadwa Țauqan, Ata'ullah Manșur, Zaki Salim Darwisy, Fauzi al-Asmar, Ahmad Yunus, Samih al-Qasim, Taufiq Zayyat, Taufĩ Fayyad, David Șaimah, Mahmud Darwisy, dan Gassan Kanafaniy. ${ }^{1}$

Para penyair menceritakan bahwa pendudukan itu menyebabkan bangsa Palestina mengalami penderitaan meskipun telah melakukan perlawanan. Akan tetapi, perlawanan itu tidak berimbang karena bangsa Palestina tidak berdaya melawan orang-orang Israel, bahkan mereka diusir ke luar negaranya, dan bangsa Palestina hidup di pengungsian yang menyebabkan kehidupan mereka menjadi bertambah buruk. Demikian pula, mereka mengungkapkan kesengsaraan yang dialami oleh para pengungsi sehingga membangkitkan tekad mereka untuk kematian.

Puisi Perlawanan (Adab al-muqawwamah) timbul akibat keprihatinan yang dialami oleh bangsa Palestina, baik di luar Palestina maupun yang masih di dalamnya. Bagi bangsa Palestina yang berada di luar negaranya, kehidupan di pengungsian merupakan penderitaan yang berat karena ketidak pastian dalam berbagai segi. Sama halnya dengan bangsa Palestina yang berada di Gaza dan Tepi Barat juga mengalami penderitaan karena kedua wilayah itu sebenarnya telah dikuasai Israel. Mereka tidak diizinkan menggunakan bahasa Arab dan harus menggunakan bahasa Ibrani. Dalam hal pendidikan, bangsa Palestina tidak mendapatkan kesempatan yang layak, maksimal hanya diberi kesempatan di sekolah dasar dan dengan mata pelajaran yang telah

\footnotetext{
${ }^{1}$ Abdurrahman Yagi, Fi-Adabil Filastiniyyil-Hadīs: Qabla an-Nakbah Wa Ba'dahā (Kuwait: Syirkah Kazimah lin-nasyri wat Tauzi` wat-Tarjamah, 1984). 20
} 
ditentukan oleh Israel. ${ }^{2}$ Penderitaan itu membangkitkan perlawanan yang di antaranya adalah perlawanan dengan kata-kata yang menurut Kanafaniy "tidak kalah tajamnya daripada perlawanan dengan senjata". ${ }^{3}$ Adab almuqawwamah dianggap sebagai bentuk perlawanan setiap bentuk penjajahan sehingga kata menggantikan fungsi senjata di medan peperangan. Adab almuqawwamah yang semula belum dikenal dalam sastra Arab, pada awalnya dimunculkan dengan menekankan pada karya sastra yang ditulis oleh para sastrawan Palestina dan tentang Palestina yang diduduki Israel. ${ }^{4}$

Begitu besarnya peranan sastra dalam sebuah pergerakan menjadikan sastra hidup bersamaan dengan komunitas masyarakat tertentu. Karya sastra menjadi seni yang tersusun dari kata-kata menjadi prasa yang indan penuh makna, dan mengandung estetik (keindahan). Sastra dan nilai-nilai kehidupan merupakan satu kesatuan esensial yang kemudian termanifestasi menjadi nilai-nilai eksistensial. Sebagai nilai eksistensial, sastra mempunyai fungsi untuk menjelaskan sebagian peristiwa dalam bingkai imajinatif. Sebagai karya yang memuat imajinasi dan fiksi, telah membuka peluang baru dalam memberikan solusi berbagai problem yang bersifat humanis. Penulis sastra menggunakan penghayan untuk mengungkapkan dengan penuh totalitas terhadap kejadian-kejadian masa lampau melalui fiksi secara subjektif. Fiksi merupakan hasil negosiasi pemahaman seseorang terhadap lingkungan dan kehidupannya. Inilah mengapa penulis fiksi mengajak pembaca memasuki pengalaman atau imajinasinya dalam karya sastra. ${ }^{5}$

Eksistensi karya sastra merupakan hasil dari proses perenungan mendalam seorang pujangga terhadap, pengalaman, gaya dan alur sehingga membedakan satu dengan yang lainnya, terutama ketika mengarang suatu karya tersebut. Penciptaan tersebut bersifat individualis, dengan kata lain cara dan gaya yang dipakai seorang pengarang dalam menciptakan suatu karya berbeda. Perbedaan tersebut bisa diliat dari metode, perenungan mendalam dan Teknik mengekspresikan isi batin sampai pada tutur dan penggunaan Bahasa saat penyampaian. ${ }^{6}$ Setidaknya ada tiga bentuk karya sastra; puisi, prosa dan drama. Dari tiga bentuk karya tersebut, puisi merupakan karya perdana yang ditulis oleh manusia untuk mengungkapkan hasil perenungan

${ }^{2}$ Gassan Kanafāniy, Al-Adabu al-Falastīniyyu al-Muqāwimu Taḥta AlIhtilāli 1948-1968, Cetakan Pertama (Beirut: Mu’assasatu ad-Dirāsāti al-Falasțīniyyati, 1968). 17

${ }^{3}$ Gassan Kanafāniy. 10

${ }^{4}$ Gassan Kanafāniy. 12

${ }^{5}$ Burhan Nurgiyantoro, Teori Pengkajian Fiksi (Yogyakarta: Gadjah Mada University Press, 1995). 3

${ }^{6}$ Waluyo, Apresiasi Puisi: Panduan Untuk Pelajar Dan Mahasiswa (Jakarta: Gramedia Pustaka Utama, 2002). 68 
mendalam secara imajinatif melalui penyususunan dan penekana pada kekuatan Bahasa serta tata kelola susunan pola karya tersebut. ${ }^{7}$

Puisi merupakan struktur susunan unsur terintegrasi dan koheren yang memiliki keterhubungan dengan yang lain membetuk satu kesatuan. Ia tidak berdiri sendiri, melainkan satu kesatuan yang terikat sehingga menjadi karya sastra yang indah. ${ }^{8}$ Inilah salah satu tahap yang paling sulit dilewati bagi seorang sastrwan, karena untuk memahami secara keseluruhan isi kandungan dari puisi harus memahami unsur pembangun dari karya tersebut. ${ }^{9}$ Oleh sebab itu, pembaca karya sastra harus memiliki kemampuan terhadap pemanfaatan Bahasa dan pendekatan yang digunakan untuk mengambil inti sari pada karya sastra; membaca karya sastra berarti melakukan penelusuran yang mendalam. Dengan kata lain, membaca karya sastra merupakan pengulangan membaca yang berkesinambungan hingga mampu mendeteksi makna terdalam yang terkandung di dalamnya. Dengan demikian pembahasan dalam kajian ini diangkat dengan pertimbanganpertimbangan tersebut di atas. Pembahasan tokoh Samih al-Qasim tidak begitu mudah ditemui, terlebih lagi tinjauan semiotika dalam salahsatu karya puisinya "Surat dari dalam Penjara" maka Nasionalisme dalam puisi-puisi Samih Al-Qasim layak untuk dibahas.

\section{METODE KAJIAN}

Tulisan ini bertujuan untuk menjabarkan semangat nasionalisme dalam puisi "Surat dari dalam Penjara" karya Samih al Qasim. Dengan menggunakan metode kualitatif melalui penelurusuran data secara ekploratif yang berbentuk lisan atau tulisan. ${ }^{10}$ Selain itu, kajian kualitatif memiliki relasi terhadap dinamika yang sedang (telah) terjadi. Oleh sebab itu, pengambilan data pada kajian ini terbagi menjadi dua, yakni primer dan sekunder. Data primer langsung diperolah dari puisi "surat dari dalam Penjara" karya Samih Al-Qasim. Sedangkan data sekunder menjadi pendukung yang diperolah dari berbagai laporan atau hasil kajian yang berkaitan dengan tema ini. ${ }^{11}$ Analisis data pada kajian ini menggunakan metode semiotika. Semiotika dalam hal ini digunakan untuk menghadirkan interaksi antara teks dengan pengalaman personal dan kultural dari pembacaan kutipan-kutipan kata, kalimat, dan

\footnotetext{
${ }^{7}$ Waluyo, Teori Dan Apresiasi Puisi (Jakarta: Erlangga, 1991). 25

8 Rachmat Djoko Pradopo, Prinsip-Prinsip Kritik Sastra (Yogyakarta: Gadjah Mada University Press, 2000). 118

${ }^{9}$ Jabrohim, Metodologi Kajian Sastra (Yogyakarta: Hanindita Graha Widya, 2003). 11

${ }^{10}$ Aminuddin, Kajian Kualitatif Dalam Bidang Bahasa Dan Sastra (Malang: Yayasan Asih Asah Asuh Malang (YA 3 Malang), 1990). 14

${ }^{11}$ Lexy J Moleong, Metode Kajian Kualitatif (Bandung: Remadja Rosdakarya, 1990). 165
} 
paragraph yang terdapat dalam puisi Samih Al-Qasim. Kajian ini dilengkapi dengan penyajian pembahasan secara deskriptif, agar nilai yang dihasilkan dari kajian puisi karya Samih al Qasim berjudul "رسـالة من المعتقل"dapat bermanfaat dengan baik dan komprehensif. ${ }^{12}$

\section{PEMBAHASAN}

\section{SELAYANG PANDANG NASIONALISME}

Pembahasan tentang nasionalisme dalam puisi Samih Al-Qasim diawali dengan penjelasan tentang nasionalisme, baik secara umum maupun khusus dalam hal ini fokus terhadap Palestina. Pada masyarakat majemuk tentu memiliki suatu tatanan nilai yang terikat dengan berbagai kepentingan untuk lebih maju dan sejahtera suatu bangsa. Inilah yang disebut dengan subideologi, ideologi nasional (nasionalis) merupakan salah satu konsesnsus yang diterapkan dibelahan dunia lain. ${ }^{13}$ Mengacu pada Besar Bahasa Indonesia (KBBI), nasional berarti bersifat kebangsaan; berkenaan dengan bangsa sendiri. Selain itu, nasionalisme juga menjadi pandangan hidup dalam bernegara, menanamkan kesadaran sebagai bagian bangsa dunia dalam menjaga perdamaian, menjunjung nilai luhur budaya sebagai identitas bangsa, menanamkan semnagt patriotism serta menyatukan tekat Bersama demi kemakmuran masyarakatnya. ${ }^{14}$

Nasionalisme secara definitif telah banyak dikemukakan oleh pakarpakar politik, Rupert Emerson memaknai nasionalisme sekelompok manusia yang merasa bahwa mereka satu atas dasar unsur dan elemen yang mengikat secara mendalam dari warisan pendahulu mereka dan memiliki tujuan yang sama di masa depan. ${ }^{15}$ Adapun Hans Kohn mengartikan nasionalisme sebagi kerangka berpikir yang tertanam pada dirinya bahwa seluruh jiwa dan raga yang paling tinggi harus diserahkan kepada tumpah darahnya. ${ }^{16}$ Lebih lanjut Kohn memberikan kategori nasionalisme menjadi dua; terbuka (open nationalism) dan tertutup (closed nationalis). Nasionalisme tertutup penanaman karakter originalitas bangsa, meliputi sejarah dan asal usul

${ }^{12}$ Winarno Surakhmad, Pengantar Kajian Ilmiah Dasar Metode Teknik (Bandung: Tarsito, 1990). 163

${ }^{13}$ Muhammad Azhar, Filsafat Politik (Yogyakarta: PT. Rajagrafindo Persada, 1997). 62

14 Pusat Bahasa Departemen Pendidikan Nasional, "Kamus Besar Bahasa Indonesia" (Jakarta: Balai Pustaka, 2005). 775

15 Saifuddin, Khilafah Vis a Vis Nation State; Telaah Atas Politik HTI (Yogyakarta: Mahameru, 2012). 56

${ }^{16}$ Hans Kohn, Nasionalisme Arti Dan Sedjarahnya, trans. Sumantri Mertodipuro (Jakarta: PT Pembangunan, 1961). 11 
bangsa. Sedangkan nasionalisme terbuka ditandai dengan keterbukaan terhadap hubungan politis yang berada diluar negara atau bangsa. ${ }^{17}$

Lathrop Stoddard dalam The New World of Islam menjelaskan nasionalisme adalah keadaan jiwa dan kepercayaan yang melekat pada jiwa raga perseorangan dan pada akhirnya membentuk kelompok yang terorganisir dalam sauatu wilayah besar, sehingga menjadi suatu bangsa dan negara yang kemudian didirikan pemerintahan untuk mengatur kehidupan. Artinya, nasionalisme menjadi pemahaman yang melekat dan diperjuangkan untuk mencapai mewujudkan kepentingan kolektif dan tujuan Bersama suatu bangsa. ${ }^{18}$

Berbeda dengan Nurcholish Majid dalam memaknai nasionalisme. Baginya, nasionalisme memiliki 5 elemen: semangat kesetiaan pada bangsa; mengutamakan kepentingan bangsa; mmenampilkan identitas bangsa; membertahanakan originalitas kebudayaan dan menghormati dan menghargai keberadaan bangsa lain. ${ }^{19}$ Sartono Kartodirdjo juga menyebutkan bahwa nasionalisme kehidupan dalam satu kesatuan pada aspek etnis, ras, sosial, kepercayaan, kebudayaan dan linguistik. Semua ini terintegrasi dalam menjalankan peran sebagai warga negara yang didasarkan pada solidaritas yang pluralistik.20

Beberapa argument diatas juga sejalan dengan apa yang dikatakan Ernest Renan menyatakan bahwa nasionalisme tidak ada penuntutan terhadap kesamaan, bagi dari segi ras, Bahasa, agama atau pun ekonomi. Semua hidup dalam perbedaan yang saling menghargai demi mewujudkan kesejahteraan bangsa. Namun Bangsa dipersatukan oleh penderitaan yang dialami bersama dan tujuan bersama. Oleh sebab itu, nasionalisme menjadi kesadaran untuk merawat dan melestarikan nilai-nilai dari leluhur atau para pahlawan yang berjuang jiwa raga untuk membangun suatu bangsa. ${ }^{21}$

Selanjutnya, Hertz menyatakan bahwa nasionalisme yang merupakan manifestasi kesadaran nasional pasti memiliki cita-cita nasional. Dalam kaitan ini, Hertz mengartikulasikan ada empat macam cita-cita nasionalisme: mewujudkan persatuan nasional pada berbagai aspek melalui asas solidaritas; kebebasan nasional agar tidak ada ikut campur orang luar dalam interfensi

\footnotetext{
${ }^{17}$ Ali Maschan Moesa, Nasionalisme Kiai: Konstruksi Sosial Berbasis Agama (Yogyakarta: PT LKIS, 2007). 30

${ }^{18}$ Gani Jumat, Nasionalisme Ulama; Pemikiran Politik Kebangsaan Sayyid 'Idrus Bin Salim Aljufri, 1891-1969 (Jakarta: Kementerian Agama RI, 2012). 31-32

${ }^{19}$ Nurcholis Madjid, Islam Kemodernan Dan Ke-Indonesiaan (Bandung: Mizan, 1999). 37

20 A. Muchtar Ghazali, PPKn Materi Kuliah Di Perguruan Tinggi Islam (Bandung: PT Remaja Rosdakarya, 2014). 37-39

${ }^{21}$ Anthonius Sitepu, Studi Ilmu Politik (Yogyakarta: Graha Ilmu, 2012). 69
} 
kehidupan bernegara; mengusakan kemandirian dalam menjalankan pemerintahan dan mengangkat harkat maerabat bangsa agar memperoleh kewibawaan, penghormatan dan pengaruh ditengan bangsa lain. ${ }^{22}$

Dari sekian definisi di atas, ditemukanlah unsur-unsur penting yang terkandung dalam nasionalisme, diantaranya:

1. Ketaatan dan kesetiaan warga negara kepada negerinya, atau cinta tanah air (patriotisme).

2. Adanya bermacam-macam unsur yang berbeda, baik etnis, kelas atau golongan, sosial, aliran kepercayaan, kebudayaan, bahasa karena nasionalisme tidak selalu memiliki unsur yang sama.

3. Memiliki kesamaan tujuan, cita-cita, dan kepentingan kolektif dalam suatu bangsa.

4. Adanya kemauan untuk bersatu dan berupaya untuk mewujudkan persatuan.

Atas dasar pengertian di atas maka makna Nasionalisme yang terkandung dalam puisi Samih al Qasim merupakan manifestasi dari kriteriakriteria yang telah disebutkan. Untuk lebih detailnya dapat dilihat di bagian akhir dalam pembahasan tulisan ini mengenai Pendidikan nilai-nilai nasionalisme yang terkandung dalam puisi Samih al Qasim.

\section{TELAAH SEMIOTIKA DALAM PUISI SAMIH AL QASIM}

Secara sederhana, pengertian semiotika ialah ilmu tanda; istilah ini diambil dari Bahasa Yunani "semeion" yang berarti "tanda". Tanda yang dimaksud disini ialah gerakan, susunan karya sastra, alur film, suara atau nada, atau bahkan suara yang berasal dari binatang. Artinya, apapun bisa dikatakan danda selama objek tersebut bisa di amati dan memiliki makna. Charles Sander Peirce menekankan bahwa manusia tidak akan mampu berpikir hanya jika melalui tanda. Melalui tandalah manusia mempu berinteraksi satu dengan yang lain, tanpa tanda kehidupan akan menjadi hampa. Hoed juga menambahkan, semiotika salah satu ilmu atau metode untuk menggali dan mengkaji lebih dalam yang berkenaan dengan tanda. Tanda telah menjadi sesuatu yang mampu mewakili manusia dalam tukar pikiran, pengalaman, perasaan, dan lain sebagainya.

Senada dengan Hoed, Preminger mengartikulasikan semiotika ialah ilmu yang mengkaji tanda. Pada posisi ini, semiotika melihat fenomena sosial atau masyarakat serta kebudayaan sebuah tanda yang bisa ditelusuri secara mendalam. Pada tahap ini, semiotika akan menelusuri sistem, aturan, dan konvensi yang memungkinkan mempunyai arti. Pada konteks karya sestra,

\footnotetext{
${ }^{22}$ Anthonius Sitepu. 70
} 
kajian semiotika mencakup analisis penggunaan Bahasa yang inhern pada (sifat-sifat) yang melahirkan berbagai cara (modus) pada wacana yang mempunyai makna. Dengan kata lain, studi semiotika merupakan kajian untuk menganalisis sistem yang terdapat pada karya sastra, baik berupa puisi, prosa dan drama.

Prinsif dalam semiotika setidaknya ada dua; penanda (signifier) atau yang menandai, yang merupakan bentuk tanda, dan petanda (signified) atau yang ditandai. Penanda adalah bentuk formalnya yang menandai sesuatu yang disebut petanda, sedangkan petanda adalah sesuatu yang ditandai oleh penanda itu yaitu artinya. Menelusuri lebih jauh mengenai tanda, maka mesti ada antara penanda dan petanda. Pierce menjelaskan ada 3 (tiga) jenis yang utama dalam sistem tanda: ikon, indeks dan symbol. Ikon adalah relasi antara penanda dan pentandanya secara alamiah, seperti ketika seseorang seorang fotografer yang sedang mengambil gambar seseorang. Adapun indeks adalah tanda yang menyiratkan relasi yang alamiah yang bersifat kausal (timbalbalik), seperti asap menandakan adanya api. Dedangkan symbol adalah tanda yangtidak mengindikasikan gejala natural antara penanda dan petanda. Relasi keduanya menekankan kausal berdasarkan kesepakatan suatu kelompok atau masyarakat. Pada posisi ini tanda melahirkan lambang atau Bahasa menjadi kesepakatan Bersama yang dilahirkan kelompok tertentu.

Bagi Saussure, Bahasa menjadi sistem tanda yang memiliki dua unsur yang tidak bisa dipisahkan; signifier dan signified, signifiant dan signifie, atau penanda dan petanda. Pada titik inilah, dalam karya sastra Bahasa menjadi sistem tanda pada tingkat pertama. Dalam semiotika, Bahasa mempunyai meaning (arti) yang sebagain dilahirkan dan disepakati oleh masyarakat. Dalam hal ini, Bahasa menjadi tanda yang memiliki arti yang telah dikonvensi dalam bentuk tanda dan menjadi semiotika tingkat kedua. Dalam karya sastra, Bahasa mempunyai berbagai konvensi yang berbeda-beda, sesuai dengan situasi kondisi yang ada. Dibalik konvebsi tersebut, Bahasa menjadi memiliki arti dalam arti (meaning of meaning). Inilah menagapa, untuk membedakannya (dari arti bahasa), arti sastra itu disebut makna (significance).

Berthes memberikan gambaran terhadap kajian semiotika lebih lanjut, baginya untuk memberikan minat yang lebih kaya terhadap dimensi makna dan kekayaan teks, harus melalui prosedur verifikasi penanda pada pembacaan naratif untuk dimasukkan kedalam fragmen ringkas dan terstruktur atau bisa disebut sebagai keksia-leksia; satuan pembacaan yang Panjang dan variatif. Selanjutnya ia menjelaskan bahawa dalam kepercayaan masyarakat (mitos) bisa dikatakan semiotic tahap kedua dari tiga dimensi; penanda, petanda dan tanda. tanda pada pengertian ini sebagai asosiasi total 
antara konsep dan imajinasi hanya menduduki posisi sebagai pananda dalam sistem kedua.

Atas dasar penjelasan di atas, puisi Samih al-Qasim akan dikaji melalui teori semiotika Peirce, dimana puisi Samih al-Qasim akan diposisikan sebagai tanda yang mengandung makna. Tujuan pengkajian ini untuk menelusuri nilainilai Pendidikan Nasionalis yang terdapat pada struktur bait-bait puisi tersebut.

\section{NILAI-NILAI PENDIDIKAN NASIONALISME DALAM PUISI SAMIH AL QASIM}

Berikut merupakan puisi yang ditulis oleh Samih Al Qasim beserta pembacaan heuristik puisi yang berjudul "Surat dari Dalam Penjara".

\section{"Surat dari dalam Penjara"23}

aku tak punya kertas, tak juga pena

tapi aku karena sengatnya panas dan getirnya nestapa tak bisa tidur, kawan bagaimana andai aku bicara lewat puisi saja, ucapku

tiba-tiba ada yang mengunjungiku melalui lubang selku yang hitam jangan pernah anggap remeh. kelelawar telah mengunjungiku

lalu pergi dengan gesitnya

ia ciumi dinding selku yang hitam lalu kusampaikan: wahai pengunjung yang berani

kabarkanlah! bukankah kau punya berita tentang dunia kami?

sungguh, tuan

sejak lama aku tak pernah membaca koran di sini

tak pernah mendengar berita

ceritakanlah tentang dunia

tentang keluarga dan orang-orang tercinta

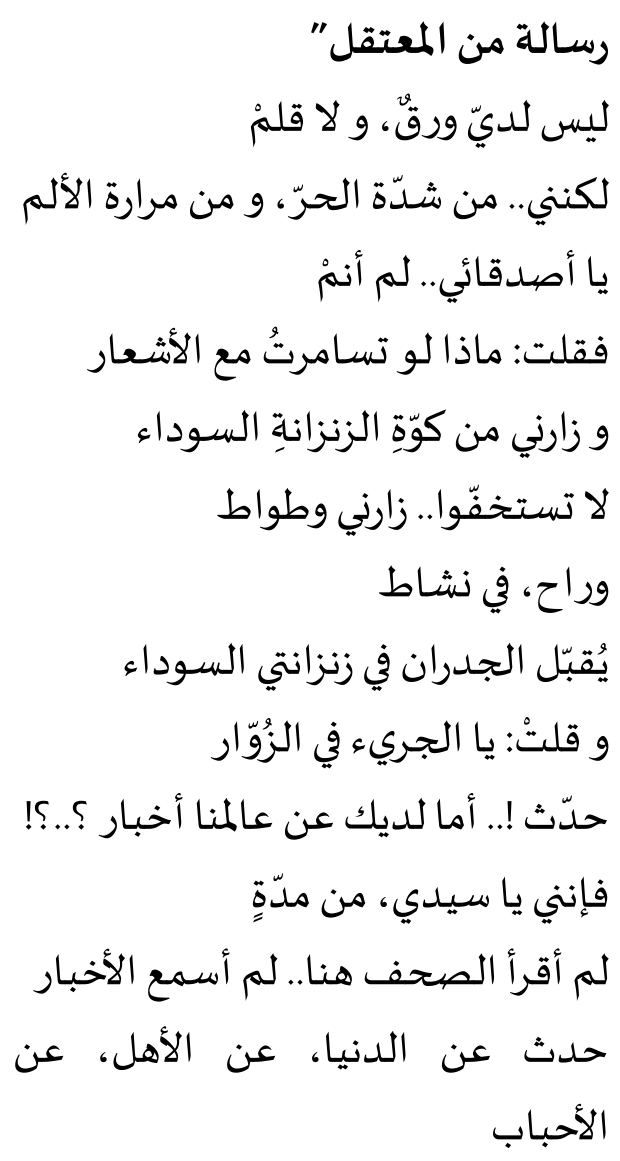


tapi ia tak menjawab!

ia mengepakkan sayap hitamnya melewati lubang. lalu terbang aku teriak: wahai pengunjung asing sebentar, tidak inginkah kau bawa berita tentangku kepada kawan-kawan **

dari panas yang menyengat, dari kecoa dan getirnya nestapa aku tak bisa tidur, kawan dan sipir yang malang masih berdiri dibelakang pintu

masih saja. tak bosan memindahkan kakinya

seperti diriku, ia pun tak bisa tidur.

seolah-olah ia diriku, dihukum tanpa alasan

$* * *$

kusandarkan punggungku ke dinding celaka! aku tercekik dalam pusaran tanpa keputusan

lalu di balik keningku pikiran berkobar ibu! betapa menyedihkannya ini

demi aku, pada malam-malam yang menyakitkan

engkau menangis dalam sunyi, kapan akan kembali

saudara-saudara tercintaku dari kesibukannya

demi aku, engkau tak bisa makan

tempat dudukku kosong, tak ada tawa, tak ada kata

ibu! betapa menyakitkannya ini kau teteskan air mata

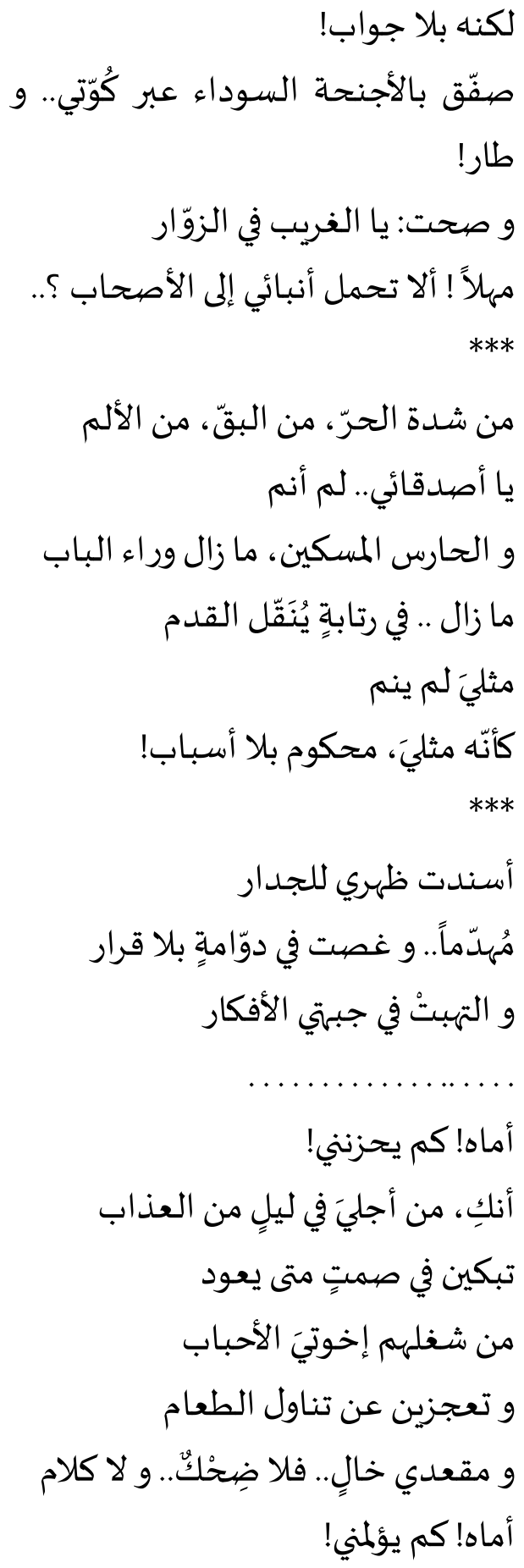

Homepage https://jurnal.stiq-amuntai.ac.id/index.php/al-miyar 
setiap kali kawan-kawanku datang bertanya

tapi aku yakin, ibu

aku yakin dalam bui ini

akan lahir keindahan hidup

aku yakin pengunjungku yang terakhir

bukan lagi kelelawar malam yang

berkelana tanpa mata

siang harus mengunjungiku

lalu para tawanan menunduk dengan penuh khidmat

bernyanyi. oh, buiku bernyanyi.

celaka! siang adalah kobaran!

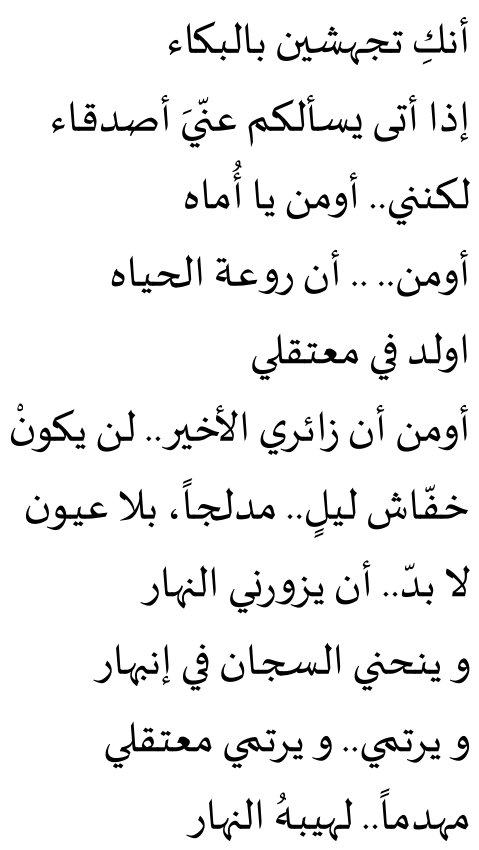

Samih al-Qasim sebagai seorang yang cinta tanah air merasakan kesedihan yang mendalam. Kesedihan mendalam akibat kehilangan saudara sebangsanya. Kehilangan saudara seagamanya sebagai akibat dari peperangan melawan Israel. Bagaimana tidak, Palestina adalah sang ibu pertiwi, tidak gentar rakyat dan pejuang Palestina untuk memerangi kesewenang-wenangan Israel yang berniat untuk mengambil tanah kelahirannya. Betapa dukungan rakyat Palestina menggebu-gebu terhadap perjuangan melawan Israel, hingga bait demi bait, puisi perlawanan pun tercipta, nasionalisme pun tumbuh dan berkembang dengan sendirinya. Perlawanan demi perlawanan yang timbul dari masyarakat Palestina baik berupa fisik maupun non-fisik dengan puisi, lagu ataupun tulisan-tulisan didasarkan pada keyakinan bahwa bangsa Palestina lah yang memiliki hak untuk tetap tinggal, sedangkan bangsa Israel hanya diperlakukan sebagai pendatang.

Dalam puisinya "Surat dari dalam Penjara" Samih al-Qasim berusaha mendiskripsikan kebiadaban bangsa Israel. Bagaimana bangsa Pendatang tersebut mengakuisisi Palestina sebagai tanah mereka. Lalu mengapa harus puisi "Surat dari dalam Penjara?" pemilihan puisi tersebut didasarkan sebagai gambaran masyarakat Palestina saat ini. Mereka terpenjara di dalam tanah kelahirannya sendiri, tak bisa berbuat banyak, hanya mampu bertahan dengan sekuat jerih payah, tanpa bantuan dan solusi yang jelas dari bangsa 
lain. Puisi "Surat dari dalam Penjara" mewakili keterasingan dan kesengsaraan masyarakat Palestina terhadap tuntutan bangsa Israel yang menduduki tanah Palestina. Bak burung dalam sangkar, sebuah kebebasan yang dibatasi dengan jeruji-jeruji besi. Sebuah kebebasan yang dijanjikan dengan syarat tunduk dan patuh terhadap tirani dan kebiadaban sebuah bangsa.

Pembacaan Heurmenetik Puisi yang Berjudul Surat dari Dalam Penjara; Samih al-Qasim dalam puisinya "Surat dari dalam Penjara" atau yang dalam Bahasa aslinya ditulis (رسالة من المعتقل) menggunakan term al-Mu'taqal untuk mendefinisikan yang dalam Bahasa Indonesia diartikan "Penjara". Hal tersebut bukan tanpa alasan, berikut adalah penjelasan tentang penggunaan term al-Mu'taqal dalam puisi "Surat dari dalam Penjara".

Menurut Bahasa; Harun Nasution menyebutkan bahwa dalam kamus Bahasa Arab dijumpai kata 'aqala yang berarti mengikat dan menahan. Sedangkan, tali pengikat perban di Arab Saudi disebut Iqal; dan I'taqala yang berarti menahan orang di dalam penjara; dari asal kata yang sama ditemukan juga Mu'taqal yang diartikan sebagai tempat tahanan. ${ }^{24}$ Dari definisi tersebut didapatkan informasi bahwa, kata Aqal pada mulanya berarti mengikat dan menahan, orang yang aqil di zaman jahiliyah atau Hamiyyah adalah orang yang dapat menahan amarahnya dengan segala kebijaksanaan yang dimilikinya, sedangkan Mu'taqal adalah tempat bagi yang tidak memiliki kebijaksanaan atau diartikan sebagai tempat tahanan.

Sedangkan ( السجنن ) Secara bahasa artinya menahan. Menahan yang dimaksud disini ialah tempat kurungan dan pembatasan pada manusia yang melakukan kesalahan. Makna ini juga sesuai dengan kamus hukum yang mengistilahkan dengan penjara. Mereka dimasukan ke Penjara dalam rangka mempertanggungjawabkan tindak kriminal.

Perbedaan definisi antara as-Sijn dan al-Mu'taqal terletak pada penggunaannya. Samih al-Qasim sengaja menggunakan term al-Mu'taqal dikarenakan dalam Bahasa Arab al-Mu'taqal digunakan untuk seseorang yang dipenjarakan tanpa pengadilan dengan alasan bahwa dia bermaksud di masa depan untuk mengambil tindakan illegal maupun tindakan-tindakan yang dapat membahayakan pemerintahan saat itu. Narasi-narasi Samih alQasim dianggap membahayakan Israel, maka di penjarakanlah ia. Namun demikian, hal tersebut tidaklah mengurangi semangatnya untuk membela

\footnotetext{
${ }^{24}$ Harun Nasution, Akal Dan Wahyu Dalam Islam (Jakarta: UI Press, 1986). 6
} 
Palestina negeri kelahirannya. Dengan kondisi dipenjara tanpa sebab dan alasan yang jelas inilah maka Samih al-Qasim membuat puisi tersebut di atas.

Lebih jelasnya al-Mu'taqal atau disebut juga sebagai penahanan administrative dilakukan tanpa melakukan pelanggaran apa pun. Dengan dalih sebagai langkah pencegahan, tidak ada batasan waktu untuk periode penahanan. Penahanan administrative tersebut dilakukan tanpa menjalani pengadilan, berdasarkan perintah yang dikeluarkan oleh komandan distrik dan dengan bukti rahasia bahkan tidak diketahui oleh tahanan itu sendiri. Prosedur ini menempatkan tahanan dalam situasi yang tidak dapat ditolerir karena ia tidak mampu menghadapi tuduhan yang tidak diketahuinya dan oleh karena itu tidak memiliki cara untuk membantahnya tanpa dakwaan atau persidangan.

Pemilihan penjara sebagai objek puisipun memiliki makna tersendiri, Samih al-Qasim dalam "Surat dari dalam Penjara" berusaha mengajarkan nilai pendidikan bahwa meskipun berada di dalam penjara, hal tersebut justru semakin menguatkan indra-indranya. Indra penciuman semakin kuat dalam membau hal-hal di sekitarnya dengan lebih baik, indra penglihatan yang mampu menembus tebalnya dinding tembok penjara menerawang ke arah cahaya rembulan, akal yang semakin terasah untuk perjuangan rakyat Palestina. Hal-hal tersebut di atas di deskripsikan untuk menunjukkan bahwa dalam keterbatasan, seorang hamba harus mampu melewati batasannya. "واتبهت فى جبهة الأفكار" (berbagai pertanyaan berkecamuk di pikiranku)

Perlu melihat bagaimana kondisi pengarang, dimana dalam posisi ini pengarang puisi sebagai seorang pembela tanah air. Hal tersebut dapat dilihat dari pekerjaannya sebagai seorang jurnalis di Haifa dimana ia juga sebagai pemimpin redaksi surat kabar Arab Israel Kul al-Arab. Sebagai seorang penyair, Samih al-Qasim banyak mengumpulkan audience lalu membacakan puisi nya sebagai bentuk perlawanan terhadap kaum zionis Israel. Dengan puisi "Surat dari dalam Penjara" Samih al-Qasim juga mengajak dan mengajarkan nilai Pendidikan kepada pemuda Palestina untuk berjuang melawan penjajahan di negeri mereka. Kesengsaraan dan penderitaan rakyat Palestina dideskripsikan dengan seorang ibu yang melihat keadaan anaknya dibalik jeruji besi tanpa makanan dan minuman yang layak, tanpa rumah untuk berteduh, yang sedang bergelut dengan kesedihan dan linangan air mata.

Adapun pada pemilihan kata "يعاقب دون السبب" (dihukum tanpa ada alasan); bagaimana seorang pemuda dapat dihukum hanya karena membela tanah airnya? Dimanakah letak kesalahan bagi seorang yang mencintai tanah 
airnya? Bukankah sudah menjadi kewajiban bagi setiap orang yang mencintai tanah airnya untuk membela tempat kelahirannya?

Puisi ini dibagi menjadi 3 buah bait, pada bait pertama menjelaskan tentang ketidakberdayaan penyair terhadap kondisinya. Tetapi, hal tersebut tidak membuatnya kehilangan asa untuk berjuang. "aku tak punya kertas, tak juga pena tapi aku karena sengatnya panas dan getirnya nestapa tak bisa tidur, kawan bagaimana andai aku bicara lewat puisi saja, ucapku". Perjuangan tidak hanya menggunakan fisik semata, jika hidup terbatas dengan umur, maka tidaklah sama halnya dengan tulisan yang akan selalu terukir di sanubari para pejuang. Penyair menggunakan keteraturan rima dalam puisi nya. Hal tersebut dapat dilihat pada tiap akhir kata yang diakhiri dengan huruf Mim:

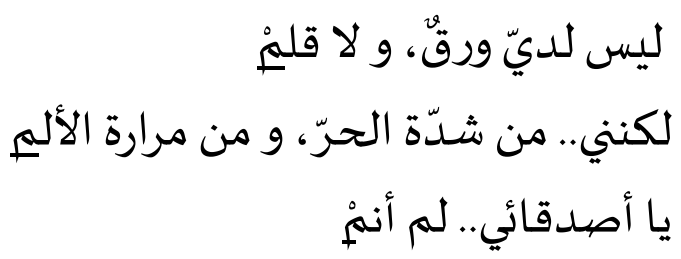

Selanjutnya, "tiba-tiba ada yang mengunjungiku melalui lubang selku yang hitam jangan pernah anggap remeh. kelelawar telah mengunjungiku lalu pergi dengan gesitnya ia ciumi dinding selku yang hitam lalu kusampaikan: wahai pengunjung yang berani kabarkanlah! bukankah kau punya berita tentang dunia kami?".

Semua orang pasti akan bertemu dengan kematian. Tetapi kematian yang paling menyedihkan adalah dilupakan oleh rekan seperjuangan, dilupakan oleh hingar bingar kejadian yang berlalu dan melintas begitu saja. Dalam bait ini, menjelaskan betapa kerinduan penyair begitu besar terhadap hal-hal tang terjadi di luar, perjuangan yang berlalu tanpanya seakan sebuah perjuangan yang singkat; datang dan pergi begitu saja bak kelelawar yang hinggap dan melintas untuk mengistirahatkan sayapnya. Nilai Pendidikan yang terdapat pada bait ini agar melaksanakan segala apapun dengan sungguh-sungguh.

Selanjutnya, "sungguh, tuan sejak lama aku tak pernah membaca koran di sini tak pernah mendengar berita ceritakanlah tentang dunia tentang keluarga dan orang-orang tercinta tapi ia tak menjawab! ia mengepakkan sayap hitamnya melewati lubang. lalu terbang aku teriak: wahai pengunjung asing sebentar, tidak inginkah kau bawa berita tentangku kepada kawankawan".

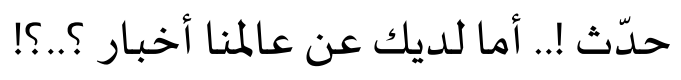




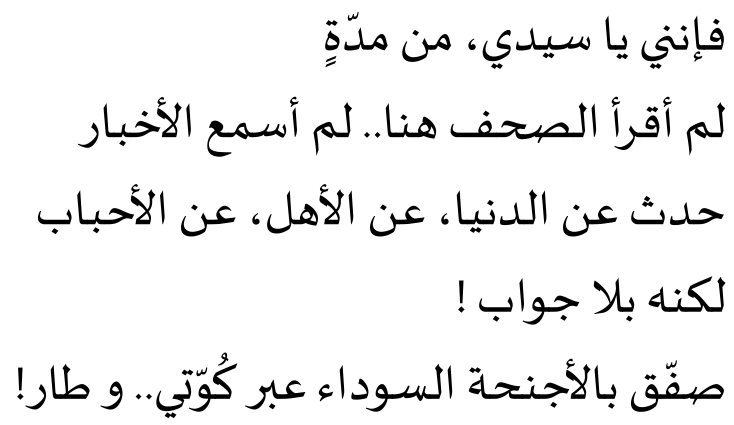

Nilai-nilai Pendidikan nasionalis yang terkandung pada keseluruhan bait pertama menceritakan tentang kehidupan penyair saat di penjara. Samih al-Qasim dikenal sebagai seorang penyair yang giat memperjuangkan palestina, giat menyerukan keadaan-keadaan masyarakat Palestina kepada seluruh dunia. Hal tersebut dilakukannya melalui bait-bait puisinya. Bagaimana ia mengungkapkan fakta yang terjadi tidaklah semanis pemberitaan yang dimuat media. Berkat puisi-puisinya akhirnya ia kini harus mengistirahatkan dirinya dibalik jeruji-jeruji besi.

Samih al-Qasim memang telah dipenjara, meskipun demikian fakta tersebut tidak membuatnya berhenti untuk menulis. Dari balik jeruji besi terciptalah puisi yang memberikan semangat bagi masyarakat Palestina dan pada dunia secara umum, bahwa dirinya akan tetap berjuang dengan caranya. Walaupun tanpa secarik kertas dan pena, ia akan tetap mengukir bait-bait puisi yang menceritakan perjuangannya dalam mendapatkan keadilan dan perdamaian. Selama dirinya di dalam penjara, rasa khawatir dan hasrat keingintahuan tentang keadaan saudara-saudara seperjuangannya selalu datang dan membuatnya gelisah. Kegelisahan yang menumpuk membuatnya tetap tersadar bahwa perjuangannya belum berakhir. Ia harus tetap tersadar untuk melihat pagi di keesokan hari.

Pada bait kedua; "dari panas yang menyengat, dari kecoa dan getirnya nestapa aku tak bisa tidur, kawan dan sipir yang malang masih berdiri dibelakang pintu masih saja. tak bosan memindahkan kakinya seperti diriku, ia pun tak bisa tidur. seolah-olah ia diriku, dihukum tanpa alasan". Pada bait kedua ini penyair menggunakan sarana retorika berupa gaya ironi, yang menyatakan sesuatu secara kebalikan untuk menyindir keadaan. Penyair membandingkan keadaan seorang sipir dengan dirinya yang sedang dipenjara tanpa kesalahan yang jelas. "dari panas yang menyengat, dari kecoa dan getirnya nestapa aku tak bisa tidur". Sedangkan di awal bait penyair menceritakan keadaannya yang sangat ironis. Sebuah keadaan dimana penyair harus melepas lelah dalam penatnya sebuah kurungan sel penjara, dari bau dan aroma yang keluar dari berbagai makhluk di dalamnya, hal 
tersebut digunakan penyair untuk mengungkapkan bagaimana penyair tidak bisa mengistirahatkan kedua kelopak matanya.

Perhatikan pola rima yang digunakan penyair, kali ini penyair menggunakan pola (mim-mim-ba dan begitu pula selanjutnya mim-mim-ba)

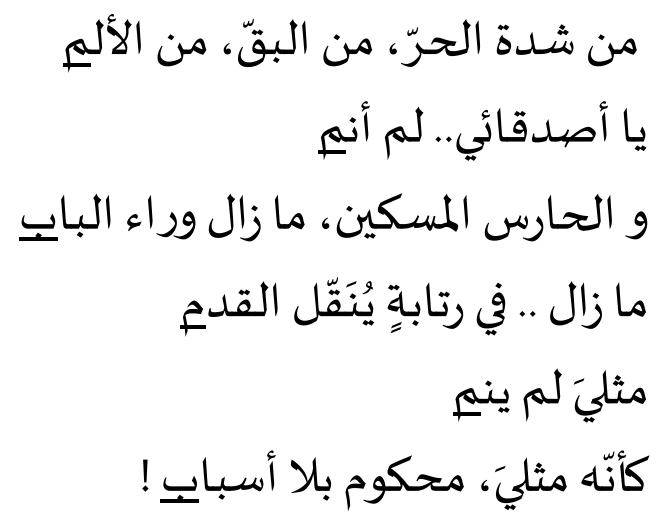

Nilai-nilai Pendidikan nasionalis yang terkandung pada keseluruhan bait kedua; dalam bait kedua, Samih al-Qasim menceritakan tentang keadaan sel penjara yang panas dan diselimuti bau tidak sedap. Bau tidak sedap di sebutkannya dengan menyebutkan seekor kecoa, tidak hanya itu penyair juga berusaha menjelaskan definisi sebuah kebebasan. Dalam puisinya ia menceritakan keadaan seorang sipir yang tidak merasakan kebebasan meskipun dirinya tidak berada di dalam penjara. Seorang sipir yang bebas tetapi terikat dengan tugas dan kewajibannya. Bahkan dalam menjalankan kewajibannya ia sebenarnya terkekang dan tidak dapat menikmati kebebasannya. Maka apalah arti kebebasan? Apakah kebebasan di dapat jika dirinya berada di luar penjara? Apakah kebebasan dapat ia rasakan saat ia di dalam penjara?

Pada bait ke-3; "kusandarkan punggungku ke dinding celaka! aku tercekik dalam pusaran tanpa keputusan lalu di balik keningku pikiran berkobar ibu! betapa menyedihkannya ini demi aku, pada malam-malam yang menyakitkan engkau menangis dalam sunyi, kapan akan kembali saudarasaudara tercintaku dari kesibukannya demi aku, engkau tak bisa makan tempat dudukku kosong, tak ada tawa, tak ada kata ibu! betapa menyakitkannya ini kau teteskan air mata setiap kali kawan-kawanku datang bertanya tapi aku yakin, ibu aku yakin dalam bui ini akan lahir keindahan hidup aku yakin pengunjungku yang terakhir bukan lagi kelelawar malam yang berkelana tanpa mata siang harus mengunjungiku lalu para tawanan menunduk dengan penuh khidmat bernyanyi. oh, buiku bernyanyi. celaka! siang adalah kobaran!". Pada awal bait ke-3, penyair kembali menggunakan kesamaan rima dalam penulisan puisinya. Hal tersebut dapat dilihat pada 
puisinya di bawah ini:

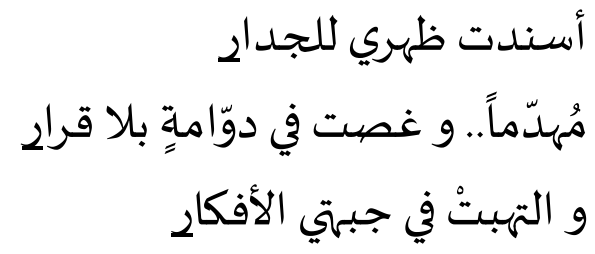

Nilai-nilai Pendidikan nasionalis yang terkandung pada keseluruhan bait ketiga adalah gambaran kehidupan sebuah keluarga dimana seorang ibu akan merasa sedih apabila tidak mengetahui kabar anaknya. Dalam bait terakhir ini, penyair berusaha menceritakan keadaan penduduk Palestina, dimana seorang ibu akan merasa kehilangan saat buah hatinya telah dipanggil Tuhan di usia yang masih sangat muda. Sebuah kesedihan yang mendalam bagi sebuah keluarga yang kehilangan anggota keluarganya. Meskipun demikian ia tetap berharap bahwa meskipun kebebasan tidak hanya berarti ia harus keluar dari bui, tetapi sebuah kebebasan yang lebih indah yaitu bebas untuk beribadah dan menjalankan ajaran agamanya di tanah kelahirannya.

Berikut daftar tabel makna yang terkandung dalam puisi Surat dari dalam Penjara Samih al Qasim:

\begin{tabular}{|c|c|c|}
\hline Judul Puisi & Makna yang terkandung dalam Puisi & $\begin{array}{c}\text { Makna Sentral } \\
\text { (Tema) pada Puisi }\end{array}$ \\
\hline $\begin{array}{l}\text { Surat dari } \\
\text { dalam } \\
\text { Penjara }\end{array}$ & \begin{tabular}{lrr}
\multicolumn{3}{l}{ Kesedihan yang mendalam penyair } \\
diungkapkan & dengan & kehilangan \\
kebebasannya. Hal & tersebut \\
dikarenakan kebebasannya & direnggut \\
secara paksa. & & \\
\end{tabular} & $\begin{array}{l}\text { Perjuangan untuk } \\
\text { kebebasan } \\
\text { Palestina }\end{array}$ \\
\hline & $\begin{array}{l}\text { Penderitaan seorang yang di asingkan } \\
\text { di dalam sebuah penjara. Kondisi social } \\
\text { dan politik yang mengharuskannya } \\
\text { untuk tetap berjuang. Berkat } \\
\text { diasingkannya ke dalam sebuah } \\
\text { penjara, penyair dapat merasakan arti } \\
\text { dari sebuah kebebasan yang } \\
\text { sebenarnya. Menambah khazanah } \\
\text { karya-karya spektakuler yang terlahir } \\
\text { dari dalam balik jeruji besi. }\end{array}$ & \\
\hline
\end{tabular}


Kebebasan harus diperjuangkan

meskipun hanya dengan sebuah tulisan

\section{KESIMPULAN}

Samih al-Qasim adalah salah satu penyair Palestina yang paling dicintai dan paling produktif. Karyanya mencontohkan puisi perlawanan yang selama beberapa dekade berasal dari dalam wilayah yang diduduki oleh Israel pada tahun 1948. Nilai Pendidikan nasionalisme merupakan poin yang diunggah untuk dijadikan sebagai tema umum dalam pembahasan puisi Samih al-Qasim. Dengan puisinya "Surat dari dalam Penjara" Samih al-Qasim telah mengajak kepada pemuda Palestina untuk berjuang melawan penjajahan di negeri mereka. Kesengsaraan dan penderitaan rakyat Palestina dideskripsikan dengan seorang ibu yang melihat keadaan anaknya dibalik jeruji besi tanpa makanan dan minuman yang layak, tanpa rumah untuk berteduh, yang sedang bergelut dengan kesedihan dan linangan air mata. Nasionalisme ini dikobarkanya lewat tulisan karyanya.

Dalam dunia sastra Samih al-Qasim sendiri mulai bisa diperhitungkan karyanya ketika karyanya yang berjudul "Surat dari Dalam Penjara, Lebih Sedih Daripada Hujan" menjadi daya tarik para pemikir baik muslim maupun non muslim pada zaman modern. Dalam karyanya tersebut Samih al-Qasim sangat kental corak sastranya dengan perihal penderitaan dan perjuangan. Pembahasan tentang nilai Pendidikan nasionalisme dalam puisi Samih AlQasim diawali dengan penjelasan tentang nasionalisme, baik secara umum maupun khusus dalam hal ini fokus terhadap Palestina. Dalam masyarakat majemuk memiliki pandangan atau sistem nilai yang dipegang sebagai landasan untuk memajukan kepentingan-kepentingan bangsa. Sistem nilai itu dapat disebut sebagai subideologi. Dalam hal ini ideologi nasional (Nasionalisme) merupakan salah satu konsensus yang banyak di terapkan di berbagai negara.

Gaya bahasanya yang lugas telah menjadikan karya sastranya puitis. Puisi yang dibahas berjudul Surat dari Dalam Penjara dibagi menjadi 3 buah bait, salah satu bait menjelaskan tentang ketidak berdayaan penyair terhadap kondisinya. Dalam hal ini Samih al-Qasim mencoba memaparkan puisi sesuai dengan realita yang ada baik dirinya maupun sekitarnya. Tetapi, hal tersebut tidak membuatnya kehilangan asa untuk berjuang. "aku tak punya kertas, tak juga pena tapi aku karena sengatnya panas dan getirnya nestapa tak bisa tidur, kawan bagaimana andai aku bicara lewat puisi saja, ucapku". Perjuangan tidak hanya menggunakan fisik semata, jika hidup terbatas dengan umur, maka tidaklah sama halnya dengan tulisan yang akan selalu terukir di sanubari para pejuang. Penyair menggunakan keteraturan rima 
dalam puisi nya

\section{SARAN}

Pembahasan tentang corak nasionalisme yang dikumandangkan Samih al-Qasim sangatlah bagus untuk dicermati oleh kita sebagai akademisi. Penulisan yang disuguhkan penulis kali ini mungkin masih banyak hal yang perlu disempurnakan. Hal ini dikarenakan kekurangan penulis dalam mencari referensi. Bahasa Arab yang digunakan oleh para kaum Arab berbeda beda jenis dan pengucapanya baik dari daerah satu dengan daerah lainya. Dalam hal ini penulis menemukan kesusahan dalam memahami karyakarya yang ditulis menggunakan bahasa Arab. Secara keseluruhan penulisan ini masihlah banyak mengandung kekurangan, dan semoga seiring berjalanya dan berkembangnya dunia keilmuan khususnya bidang sastra bisa mengembangkan lebih lanjut karya ini.

\section{DAFTAR PUSTAKA}

Azhar, Muhammad. Filsafat Politik. Yogyakarta: PT. Rajagrafindo Persada, 1997.

Aminuddin, Aminuddin. Kajian Kualitatif Dalam Bidang Bahasa Dan Sastra. Malang: Yayasan Asih Asah Asuh Malang (YA 3 Malang), 1990.

Ghazali, A. Muchtar. PPKn Materi Kuliah Di Perguruan Tinggi Islam. Bandung: PT Remaja Rosdakarya, 2014.

Jabrohim, Jabrohim. Metodologi Kajian Sastra. Yogyakarta: Hanindita Graha Widya, 2003.

Jumat, Gani. Nasionalisme Ulama; Pemikiran Politik Kebangsaan Sayyid 'Idrus Bin Salim Aljufri, 1891-1969. Jakarta: Kementerian Agama RI, 2012.

Madjid, Nurcholis. Islam Kemodernan Dan Ke-Indonesiaan. Bandung: Mizan, 1999.

Moesa, Ali Maschan. Nasionalisme Kiai; Konstruksi Sosial Berbasis Agama. Yogyakarta: PT LKIS, 2007.

Nasution, Harun. Akal Dan Wahyu Dalam Islam. Jakarta: UI Press, 1986.

Nurgiyantoro, Burhan. Teori Pengkajian Fiksi. Yogyakarta: Gadjah Mada University Press, 1995.

Kanafāniy, Gassan. Al-Adabu al-Falastīniyyu al-Muqāwimu Taḥta Altḥtilāli 1948-1968. Cetakan Pertama. Beirut: Mu’assasatu ad-Dirāsāti alFalastīniyyati, 1968.

Kohn, Hans. Nasionalisme Arti Dan Sedjarahnya. Translated by Sumantri Mertodipuro. Jakarta: PT Pembangunan, 1961. 
Moleong, Lexy J. Metode Kajian Kualitatif. Bandung: Remadja Rosdakarya, 1990.

Pusat Bahasa Departemen Pendidikan Nasional. "Kamus Besar Bahasa Indonesia." Jakarta: Balai Pustaka, 2005.

Pradopo, Rachmat Djoko. Prinsip-Prinsip Kritik Sastra. Yogyakarta: Gadjah Mada University Press, 2000.

Saifuddin, Saifuddin. Khilafah Vis a Vis Nation State; Telaah Atas Politik HTI. Yogyakarta: Mahameru, 2012.

Sitepu, Anthonius. Studi Ilmu Politik. Yogyakarta: Graha Ilmu, 2012.

Surakhmad, Winarno. Pengantar Kajian Ilmiah Dasar Metode Teknik. Bandung: Tarsito, 1990.

Waluyo, Waluyo. Apresiasi Puisi: Panduan Untuk Pelajar Dan Mahasiswa. Jakarta: Gramedia Pustaka Utama, 2002.

-_- Teori Dan Apresiasi Puisi. Jakarta: Erlangga, 1991.

Yagi, Abdurrahman. Fi-Adabil Filasținiyyil-Hadīs: Qabla an-Nakbah Wa $B a^{\prime} d a h \bar{a}$. Kuwait: Syirkah Kazimah lin-nasyri wat Tauzi watTarjamah, 1984. 